\title{
Variegated transnational partnerships: Multi-scalar actor networks in China's overseas industrial parks
}

\author{
SONG Tao ${ }^{1,2}$, SUN Man ${ }^{1,2},{ }^{*}$ LIANG Yutian ${ }^{3,4}$, Soavapa NGAMPRAMUAN ${ }^{5}$, \\ WUZHATI Yeerken ${ }^{1,2}$, ZHOU Keyang ${ }^{3}$
}

1. Institute of Geographic Sciences and Natural Resource Research, CAS, Beijing 100101, China;

2. College of Resources and Environment, University of Chinese Academy of Sciences, Beijing 100190, China;

3. School of Geography and Planning, Sun Yat-Sen University, Guangzhou 510275, China;

4. Southern Marine Science and Engineering Guangdong Laboratory (Zhuhai), Zhuhai 519080, Guangdong, China;

5. Faculty of Political Science, Department of International Relations, Ramkhamhaeng University, Bangkok, Thailand

\begin{abstract}
The development of overseas industrial parks is a key component of the Belt and Road Initiative and a practical way of promoting inclusive globalization by introducing new forms of cooperation between China and the host countries. In this paper, the Thai-Chinese Rayong Industrial Zone (TCRIZ), and the China-Indonesia Economic and Trade Cooperation Zone (KITIC) are discussed in the context of the evolving development strategies and trajectories through three interrelated conceptual lenses - policy mobility, actor networks, and partnerships. The actor-network theory provides a lens to analyze how policy mobility and partnerships develop for two industrial zone case studies. The development, which involves a multi-scalar process, is shaped by the interactions among the national states, the regional governments and corporations against a background of globalization. Three types of transnational actor partnership networks have been identified, namely, hierarchical partnership, spontaneous partnership, and hybrid partnership. A highlight of the study is the role that the partnerships play in the process of policy mobility when it comes to the overseas industrial zones. It is argued that the partnerships are the key to achieving technology transfer on a cross-national basis, and the effectiveness of the technology transfer is dependent on partner selection and the roles of the actors in policy mobility.
\end{abstract}

Keywords: overseas industrial park; multi-scalar partnership; transnational policy transfer; Thai-Chinese Rayong Industrial Zone; China-Indonesia Economic and Trade Cooperation Zone; Belt and Road Initiative

Received: 2020-11-03 Accepted: 2021-03-17

Foundation: National Natural Science Foundation of China, No.41871114, No.41701131; Strategic Priority Research Program of Chinese Academy of Sciences, No.XDA20010103; The Second Tibetan Plateau Scientific Expedition and Research Program (STEP), No.2019QZKK1007; Fund from Bureau of International Cooperation, Chinese Academy of Sciences, No.131551KYSB20180042

Author: Song Tao (1983-), PhD and Associate Professor, specialized in regional sustainable development and globalization. E-mail: songtao@igsnrr.ac.cn

*Corresponding author: Liang Yutian (1982-), PhD and Associate Professor, specialized in economic geography and regional development research. E-mail: lytian@mail.sysu.edu.cn 


\section{Introduction}

Over the past half century, more than 2000 Special Economic Zones (SEZs), despite the use of many different names and forms for these zones, have been established throughout the world and with mixed success for attracting investment, creating employment, supporting a wider economic and social reform strategy, as well as experimenting with the application of new policies and approaches (Farole and Akinci, 2011). It has also been witnessed that China's SEZs at the local, provincial, and national levels have fostered technological and industrial development and boosted urbanization by combining foreign investment and domestic resources since the opening up of the country in 1978.

To some extent, China's overseas industrial parks are an exception since the inauguration in 2013 of the Belt and Road Initiative (BRI) and its widespread implementation in the following years. The BRI has resulted in an upsurge in China's overseas industrial parks and serves as a practical way of promoting inclusive globalization by inventing new forms of cooperation between China and the local host countries (Song et al., 2018). According to the Visions and Actions document (National Development Reform Commission, Ministry of Foreign Affairs, China), the BRI draws on Chinese characteristics and attaches great importance to the willing participation of the host country such that mutual advantages (including benefits to local residents and local and national development) accrue from formation of the transnational SEZs and from enhancement of the resulting interconnectivities (Liu and Dunford, 2016; Song et al., 2018).

There are, however, noticeable differences between China's overseas SEZs and China's domestic counterparts (Ye et al., 2020; Song et al., 2018). Different industrial ventures, including both state-owned enterprises and private companies, develop in various transnational contexts, and the broader regional implications of the surges in Chinese industrial investment are under-explored (Giannecchini, 2018). The roles of leading enterprises and cooperative enterprises, local governments, local residents, and non-governmental organizations (NGOs) in SEZs should never be neglected and all require much greater attention to ensure a better conception of 'embeddedness'; that is to say, enterprise agendas and interrelationships tend to shape the role of the networks (Song et al., 2018).

In the context of the academic literature and the global media, the latter of which is dominated by transnational policy transfer (TPT) (Miao, 2018), diffusion (Marsh, 2009), and policy mobility (McCann, 2012), this article challenges simplistic depictions of Chinese overseas SEZs as copies of 'successful' domestic Industrial Parks or 'advanced' forms of Industrial Parks. Specifically, we explore the ways SEZs take shape through application of transnational multi-level governance, which is enshrined in the partnership approach. The partnership approach requires, on the one hand, vertical cooperation between the actors at the different levels of government, from the national state level down to the regional and zonal level, and, on the other hand, entails the inclusion of various public and non-state stakeholders in all stages of the decision-making and implementation processes (Dabrowski, 2014).

This paper highlights these points by shedding light on the mechanisms and outcomes for two similar partnerships in the SEZs' polycentric governance in two countries in Southeast Asia, Thailand and Indonesia. Specifically, the paper draws on case studies for two transnational partnerships of China's SEZs. Data were gathered first-hand during several field trips 
to both countries from 2015 to 2019. Several managers of the SEZs in both countries were interviewed to clarify the reasons why Chinese enterprises invested there and to better understand the roles of the enterprises. We also interviewed representatives of the Board Of Investment (BOI) in Thailand and the Business Bureau in Indonesia (BBI) to understand the respective industrial and investment histories, as well as their strategies for attracting foreign investment. In Beijing, a further 15 in-depth interviews were conducted with central government officials from the Departments of Foreign Capital and Overseas Investment, and International Cooperation within the National Development and Reform Commission, the Cooperation Department within the Ministry of Commerce, two investment banks (China Development Bank and the Export-Import Bank of China), and the State-owned Assets Supervision and Administration Commission. Most interviews were recorded and then transcribed, and the transcriptions were cross-checked with the interviewees. Information on the case study for Thailand was garnered by one of our coauthors, who was based in the country and assisted the investigation by arranging for a group of local Thai scholars to act as both translators and researchers. Numerous secondary sources of data were accessed with the help of the aforementioned local interviewees, including managers and employees of the industrial parks as well as local residents. These data included historical archives, statistical yearbooks, planning documents, and official government reports from 2013 to 2020.

The structure of the paper is as follows: Section two outlines the theoretical basis for the empirical analyses by way of outlining the variegated partnerships that characterize China's transnational SEZs. Section three details the two case studies on Chinese transnational SEZs in Southeast Asia and presents the results for empirical analysis of the partnerships involving the actors and institutions in the SEZs' governance. Section four considers the issues and challenges, as well as the implications of these experiences for China's SEZs, which invariably contribute to the growth of the partnership network in countries of the BRI.

\section{Theory on transnational partnerships among overseas SEZs}

\subsection{Extra-territorial SEZs}

There is now a very substantial body of knowledge on SEZs as both a development instrument and a geographical experiment in the fields of economics, political science, and social science (Moberg, 2017). The establishment of SEZs has been described as the exploration of place-based policies, regionalism, state territory, etc., and the topic is attracting much attention from researchers given that Southeast Asian countries including Singapore and Vietnam have experienced tremendous economic growth in the last half century (Huang et al., 2016). In particular, China, since the 1980s, has promoted the large-scale development of SEZs, which include industrial development zones, economic and technological development zones, high-tech development zones, bonded zones, border cooperation zones, and free trade zones to stimulate urban and industrial restructuring and the economy (Cheng et al., 2017; Liang et al., 2019). More recent work concerning geographical analysis of SEZs has used the terms 'China Model,' 'Experimentalism,' and 'State Capitalism' (Rithmire, 2013; Liu and Ye, 2015; Meng et al., 2015) to link this neo-liberalization trend with China's economic geographical space (referred to as SEZs), which combines the 'top-down' and 'bottom-up'

approaches. Research has actively investigated the effect of these zones on national, regional, 
and sometimes transnational growth. However, the employment, the social and environmental effects (Alkon, 2018), and also theoretical and empirical work during the past three decades has under-represented the importance of the underpinning mechanisms when SEZs were being developed and operated in different state contexts with various institutionalized regimes. In this respect, SEZs serve as sites where nation states and other actors have used targeted, spatially selected strategies to pursue integration in global market places (Ong, 2004; Doucette and Lee, 2015). It should also be noted that Asian countries, such as China, Vietnam, Indonesia, and India, have been fascinated with the economic progress made by the small city-state of Singapore, by emulating and anchoring SEZs overseas, such as the Suzhou Industrial Park (China) and the Sino-Singapore Tianjin Eco-City (China). It is argued (Phelps, 2007) that the Singapore economy has been leveraged through this particular strategy of extra-territorialization by delivering corporate networks, stimulating domestic commercial and logistical infrastructure, as well as enhancing outward direct foreign investment (OFDI). Singapore overseas SEZs have also been conceptualized as the materialization of trends towards developing and implementing authoritarian modernity and social-economic experiments (Ortmann and Thompson, 2014). However, weak governance may exist as a result of state failures and lack of capacity, but this may also arise when governments have chosen to govern parts of their territory in a differentiated or graduated manner, as in the case of SEZs, potentially resulting in the (de jure or de facto) loosening of border controls or other regulations (Holden and Chris, 2017). Seen through this lens, the cases of Singapore and China's overseas SEZs can be instructive given that this most explicit state extra-territoriality strategy reveals that the possible conceptual framework of the inter-relationships between national and international expansion requires re-thinking and further clarification.

\subsection{Transnational policy transfer and actor networks among transnational SEZs}

Confronted with such global challenges as geopolitical competition, degraded environments, and global pandemics such as COVID-19, policy-makers at different levels of authority may learn from their counterparts elsewhere. Since the 1990s, a mushrooming of the "mobilities turn,' especially in TPT studies has fueled in-depth studies on comparative politics and economic policy (Miao, 2018). Within this paradigm, policy is, thus, rebranded as it travels between internationally-based networked actors and through learning and initiatives of policymakers as part of social practice (Mccann, 2011). Clearly, there is a need for further analyses on the role of local territoriality 'in the arriving at and making up of policies,' whilst maintaining a rational view of policy formation (Ward, 2018). Actually, much attention has been given to the 'policy mobility' literature over the past decade and it is timely that more attention is being given to the role of the location and context in understanding TPT (Ortegel, 2017; Temenos and McCann, 2012).

Another approach taken to assess SEZs and which extends beyond TPT studies is the actor-network theory (ANT), whereby the SEZ is characterized by the diversity and multiplicity of the actor network. The ANT is often used as a heuristic device for explaining socio-spatial changes and institutional practices which lead to TPT. The main question explored with ANT is the following: "How do things, people, and ideas become connected and assemble in larger units?" (Czarniawska, 2017). The ANT, therefore, allows one to visualize 
the TPT process through which the mix of actors are contacted, sent invitations, enrolled, translated, and mobilized (Aka, 2019). In the context of TPT, typical functions adopted by the various actors encompass actions of the central, regional, and local governments, as well as actions by the residents, employees, and NGOs.

While we concur with the conclusions of several papers on SEZs which use the TPT and ANT approaches, by highlighting the complexity of the actor networks operating within the context of the theoretical and empirical progress made by SEZs, several limitations in these approaches clearly exist. First, the current literature suffers from a skewed case selection which arises mainly from developed countries who are the main 'policy donors' and provide 'best successful policies' (Marsh and Sharman, 2009; Miao, 2018). Second, there is a lack of nuanced actor-oriented operational research on SEZs, especially between host and local countries. Third, TPT studies tend to have been dominated by officials and consultants in the lens of the 'up to down' hierarchy. However, variegated institutional backgrounds and unbalanced multilateral contexts are a challenge to securing smooth TPT for SEZs. Against this background, it is argued that various partnerships among complex transnational contexts are central to shaping new forms of improvised territorial industrial structures on the ground, with important consequences for extra-territorial land in the future.

\subsection{Partnerships within transnational SEZs}

Since the 1990s, as broader alliances have been established between public, private, and social sectors in the context of renewed co-operation between central and local government, a more holistic interpretation of such partnerships has emerged (Adams and Hastings, 2001). The "public-private partnership" has become the policy of choice worldwide for many governments with the partnership as a concept remaining ambiguous and which urgently needs to be defined. The partnership can be defined as an organizational or institutional alliance between the actors in the public or private sectors (Kitajima, 1998; Luo and Shen, 2009). Whilst numerous studies have tracked the historical evolution of partnerships in the UK, the US, and other mature democracies, few have sought to explore how these experiences have been translated and applied in different socioeconomic or cultural circumstances (Adams and Hastings, 2001). At the same time, partnerships are encircled by discourses of 'integration' and 'participation' - discourses that are used to legitimize increasingly decentralized and multi-actor governance (Derkzen, 2010) especially within transnational SEZs. For transnational SEZs, the dual strategy of internationalization and cluster-strengthening-balancing detachment and embeddedness plays a crucial part in the success of these international firms (Taira, 2020). Transnational SEZs are constructed socially through the interactions of vertical and horizontal governance within inter-firm, intra-firm, and extra-firm networks, upon which the nation states and related political economies, as well as societal actors have imposed particular influences, thus ensuring a cohesiveness of the actor network at a local or regional level to further the SEZs' development (Chou and Lin, 2007). In contrast to vertical controls, horizontal trust is rooted within the network reciprocity, rather than in bureaucratic performance; and the power of the network lies in its contacts and influence, rather than in its authority and hierarchical status (Yeung, 2005). On the specifics, the host country and China play an equally key role in ensuring 'horizontal' cooperation among transnational SEZs. The host governments typically organize a series of platform meetings 
for strategic discussions and collaboration (Caroline et al., 2007), and invest 'political capital,' thereby providing political support for projects. Such support is critical, as it serves as a form of governance and security assurance to the transnational corporations (Pereira, 2004). At the same time, the 'bottom-up lens' needs to be emphasized by integrating all related social actors. Partnerships in local development are not just about the bringing together of the various social partners but are also about the active strengthening of local institutions and political processes for pursuing sustainable development (Stephen, 2016).

\section{Contextualizing transnational partnerships in practice: experiences of China's SEZs}

Within the lens of the ANT and the partnership approach, the partnership experiences of China's SEZs should be understood within a broader context and framework. In this study, the concept of partnership topology is borrowed from regional cooperation initiatives (Luo and Shen, 2009). These types of initiative comprise three types of partnership arrangements with different modes of transnational policy mobilization among more than 100 Chinese overseas SEZs along the BRI; specifically, these are hierarchical partnerships, spontaneous partnerships, and hybrid partnerships. These distinct partnerships are now examined separately (Table 1).

\subsection{Hierarchical partnership: a partnership dominated by state governance}

In this partnership mode, overseas SEZs serve as highly driven development instruments of the partnership which are formed by the host and the counterpart national state. A notable example of this may be found in Singapore's overseas SEZs and its regionalization strategy, such as the Suzhou Industrial Park. State involvement in township developments is through government agencies, such as the Economic Development Board, and government-affiliated companies, which support projects via their marketing networks and close links to many multi-national corporations located in Singapore (Shaw and Yeoh, 2000). The overseas regionalization strategy typically comprises state-led infrastructure projects, and a range of incentives and regulatory innovations, which are designed to assist private companies and individuals to re-locate overseas (Caroline et al., 2007).

In a similar way, some Chinese overseas SEZs may be characterized in terms of a state-led top-down approach, such as the Zambia-China Economic and Trade Cooperation Zone, and The China-Belarus Great Stone Industrial Park (Liu and Wang, 2020). The China-Belarus Great Stone Industrial Park is a good example of a close partnership formed between two countries, which ensures preferential policy treatments and marketing advantages. In such cases, the partnership reflects a relative comparability of the local and host country policies and a combination of preferential policies and guarantees (Song et al., 2018).

\subsection{Spontaneous partnership: a partnership with leading private enterprises}

Numerous initiatives exist within the BRI and these reveal a landscape of Chinese overseas SEZs led by transnational partnerships of private enterprises and which can be termed spontaneous partnerships. Actually, since the 1980s, and in the context of neo-liberalism, there 
has been a trend towards more decentralized and territorial modes of regional policy governance concerning the structure of networks comprising governmental and societal actors, and public-private partnerships, with the aim of radically improving infrastructure networks and delivering enhanced services to the residents and local economies. Such spontaneous and private-led partnerships are able to dominate the policy agendas of overseas SEZs through their apparent ability to champion and deliver the symbols of industrial development to which local politicians aspire. This aspect is well illustrated by the very influential 'flagship' projects of China's SEZs, such as the Huajian Light Manufacturing Zone in Ethiopia and the China-Laos Mohan-Moten Economic Cooperation Zone. It should also be noted that these spontaneous partnerships at first received no political favors except for profit incentives which fell within the scope of the national governments' industrialization efforts.

\subsection{Hybrid partnership: 'park-within-park' mode}

A hybrid partnership, also coined as 'park-within-park' mode, can be described as a centralized and multi-faceted partnership mode that delivers overseas SEZs. Typically, a SEZ already exists in the host country, and a leading private enterprise serves as a sub-platform to attract more private actors to re-locate into the particular industrial park. The organizational structure of the hybrid partnership can be viewed as a combination of the top-down and the bottom-up approaches. In particular, such SEZs have been driven forward by private sector business interests led by property owners and developers but which enjoy a joint partnership between the host and the local municipal actor networks. This arrangement will be discussed in detail in the next section by way of empirical analysis of two case studies, namely, the Thai-Chinese Rayong Industrial Zone (TCRIZ) (Thailand), and the Indonesia-China PT Kawasan Industrial Zone (KITIC) (Indonesia) (Figure 1).

Table 1 A comparison of the three transnational partnerships of Chinese overseas SEZs

\begin{tabular}{llll}
\hline \multicolumn{1}{c}{ Model } & \multicolumn{1}{c}{ Example } & \multicolumn{1}{c}{ Features } & \multicolumn{1}{c}{ Functions of multi-scalar actors } \\
\hline $\begin{array}{l}\text { Hierarchical part- } \\
\text { nership }\end{array}$ & $\begin{array}{l}\text { China-Belarus Great Stone } \\
\text { Industrial Park, etc. }\end{array}$ & $\begin{array}{l}\text { Government-to-government } \\
\text { joint SEZs }\end{array}$ & $\begin{array}{l}\text { Led bilaterally by national state } \\
\text { governments; implementation of } \\
\text { national partnership policies }\end{array}$ \\
$\begin{array}{l}\text { Spontaneous } \\
\text { partnership }\end{array}$ & $\begin{array}{l}\text { Integrated development zone of } \\
\text { Saiseta, Vientiane, Laos, etc. }\end{array}$ & $\begin{array}{l}\text { Led by spontaneous coopera- } \\
\text { tive efforts of private or pub- } \\
\text { lic actors }\end{array}$ & $\begin{array}{l}\text { Searching for preferred } \\
\text { outcomes; attract FDI; revenue } \\
\text { generation }\end{array}$ \\
$\begin{array}{l}\text { Hybrid partner- } \\
\text { ship }\end{array}$ & $\begin{array}{l}\text { Thai-Chinese Rayong Industrial } \\
\text { Zone;China-Indonesia Economic } \\
\text { and Trade Cooperation Zone, etc. }\end{array}$ & $\begin{array}{l}\text { Spponst arrangements by } \\
\text { national and regional gov- } \\
\text { ernments }\end{array}$ & $\begin{array}{l}\text { Led by private sector actors; } \\
\text { national and local efforts on } \\
\text { bilateral basis }\end{array}$ \\
\hline
\end{tabular}

\section{A tale of two Chinese overseas SEZs within the BRI}

An empirical analysis has been undertaken based on the experiences of two Chinese overseas SEZs operating in Thailand and Indonesia. We are not aiming to compare the two cases, instead, a detailed description is given to the hybrid partnership modes of the transnational networks, which feature national and provincial states, multi-national corporations, as well as local employees and residents.

\subsection{Thai-Chinese Rayong Industrial Zone}

The TCRIZ is China's flagship industrial park project in Thailand (Song et al., 2020) (Table 
2). First proposed in 2006 by $\mathrm{Hu}$ Jintao, the then Chinese president, the TCRIZ was established in Amata City Industrial Estate, Rayong, in eastern Thailand. The total planned area for the TCRIZ was $12 \mathrm{~km}^{2}$, of which phases I and II ( $4 \mathrm{~km}^{2}$ in total) have been fully developed as of May 2020. Phase III projects have commenced with a focus being given to attracting medium- and high-end manufacturing enterprises. At present, a satisfactory industrial agglomeration effect has been consolidated in the study area. There are more than 150 Chinese enterprises engaged in automotive, new energy, building materials, machinery, electronics, and computing activities, employing 32,000 Thai employees and 2000 Chinese employees with a total output value of 12 billion USD.

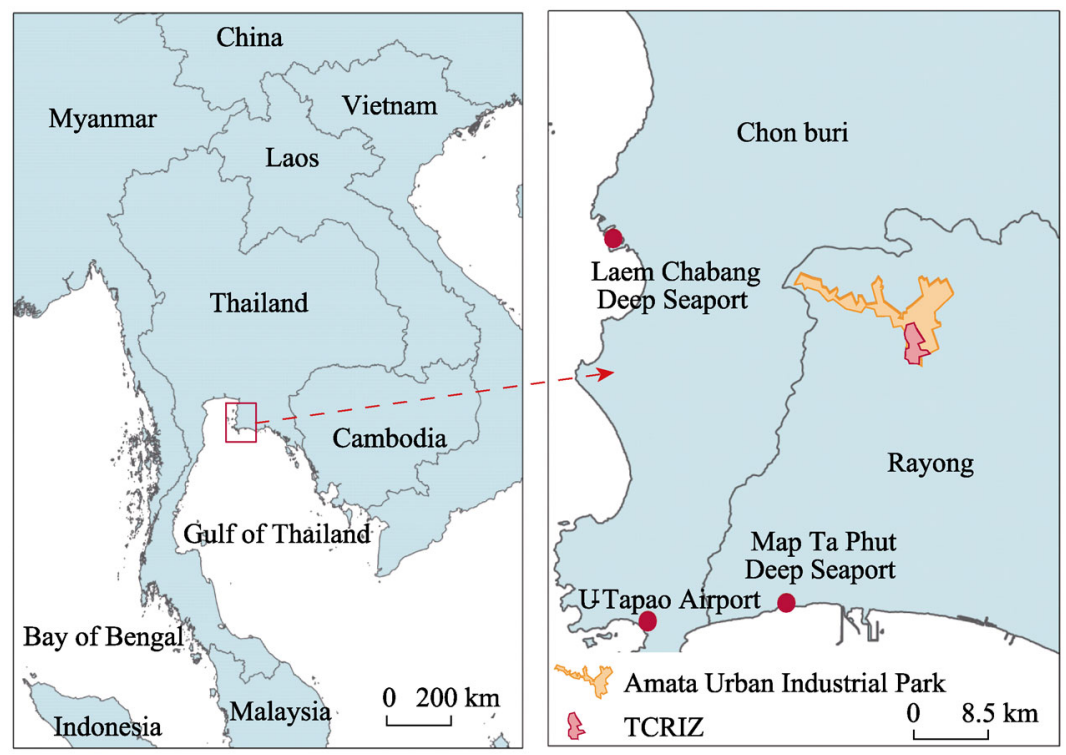

Figure 1 Location of the Thai-Chinese Rayong Industrial Zone

The Holley Group, which serves as the main actor for the TCRIZ, has witnessed significant growth and entrepreneurialism since it was founded as the 'Bamboo Rain Gear Factory' in Yuhang Town, Zhejiang Province in 1970. Holley Group had evolved into an industrial enterprise primarily as a result of producing electricity (watt-hour) meters in 1971; the release of the 'Holley' trademark ('Huali' in Chinese) occurred in 1982. The Holley Group was upgraded to one of the leading enterprises in China's electrical industry, its business strategy being described in 2000 as: "Capital management, technological innovation, and internationalization." Meanwhile, the 'going out policy' initiated by the government (national level) in 1999 led to a wave of enterprises around the country adopting a similar business strategy.

A series of steps were taken by Holley to realize internationalization of their business strategy. One of the key steps was to establish a series of industrial plants in Thailand, which would be attractive for both Thai and foreign investment due to the creation of a business-friendly economic and environmental situation. In 2000, Holley (Thailand) Electric Co. Ltd. was established to produce electricity meters for Thailand, ASEAN countries, European and American markets. Some three years later, Holley set up the Qianjiang Trading Company in Thailand to accelerate trade deals in the import and export of electrical appliances 
between China and Thailand. In sum, the early entrepreneurial endeavors of the Holley Group began through application of the industrialization policies on the east coast of Thailand in the early 1990s, which entailed an effective internationalization strategy to expand production and extend their market networks throughout the world. A strong scaling up of production and partnering efforts are revealed in this actor network. However, entrepreneurial policies that thrive in home countries may not necessarily bear fruit in overseas regions, as they can assume a variegated institutional environment, partnership will debut and play a key role in TPT of overseas industrial zones.

The operating mode of the TCRIZ can be best described as operating as a 'garden within garden.' In this regard, the Thai private counterpart company, the Amata Corporation Public Company Ltd (Amata Company), was in charge of establishing the TCRIZ and this played a crucial role in being able to better understand partnership formation with policy mobility. The Amata Company was founded in 1989 by Vikrom Kromadit ('Qiu Weigong'in Chinese), and listed in the Stock Exchange of Thailand (SET) in 1997. It was labeled as 'a successful developer of industrial estates' given that it enjoyed a market share of about $40 \%$ in the development and transfer of industrial land in Thailand. The TCRIZ is adjacent to the Amata City Industrial Estate in Rayong, one of four industrial parks (local and overseas) built and operated by Amata (Table 2). The other three are the Amata Nakorn Industrial Estate, Chonburi, the Amata City (Bien Hoa), Vietnam, and the Amata City Long Thanh, Vietnam. All of these industrial parks have been positioned as "Smart \& Intelligent Cities" with the capabilities to create cities with sustainable growth. In this regard, the Amata Company's success can be attributed to its remarkable achievement in industrial zoning, which strongly supported policymakers to push for, in 2016, a value-based economy (termed the 'Thailand 4.0' initiative) by undertaking reform of its existing major industry clusters. It is worth noting that the Amata Company's experiences in industrial development and its close relationship with the Thai government have had far-reaching influences on the establishment and operation of the TCRIZ.

Table 2 Strategic cooperative partnerships in the Thai-Chinese Rayong Industrial Zone (Song et al., 2020)

\begin{tabular}{|c|c|c|}
\hline & Thailand & China \\
\hline State level & The Board of Investment & China's Ministry of Commerce \\
\hline Provincial level & Rayong & Zhejiang Province \\
\hline Company level & Amata Company & Holley Group \\
\hline $\begin{array}{l}\text { Co-partnership company } \\
\text { (Thai-Chinese Rayong In- } \\
\text { dustrial Zone Development } \\
\text { Company Limited) }\end{array}$ & $30 \%$ of the shares & $70 \%$ of the shares \\
\hline Division of work & $\begin{array}{l}\text { The Thai side is mainly responsible } \\
\text { for infrastructure construction in- } \\
\text { cluding water supply, power supply, } \\
\text { roads, and workshops; supply of land } \\
\text { and permanent ownership; recruit- } \\
\text { ment of Thai staff. }\end{array}$ & $\begin{array}{l}\text { Enterprise selection and format control; provision } \\
\text { of one-stop services for Chinese enterprises, in- } \\
\text { cluding company registration, tax, account open- } \\
\text { ing and application for BOI qualification certifi- } \\
\text { cate; consulting services on target markets, indus- } \\
\text { trial policies, laws and regulations, preferential } \\
\text { policies, tax finance, labor recruitment. }\end{array}$ \\
\hline
\end{tabular}

The most striking feature in the composition of the TCRIZ partnership is the multi-level partnerships within the transnational actor network. Since the establishment of diplomatic 
relations between China and Thailand in 1971, the China-Thailand bilateral relationship has moved forward steadily and was upgraded to a comprehensive strategic partnership in 2012. Also, since the BRI was initiated in 2013, the TCRIZ was enrolled as a member of the national flagship project. At the state level, the Thai central government granted favored status to the zoned areas, which were characterized as having preferential policies for the BOI phase III zones, for the purpose of attracting OFDI from China. These policies included preferential policies on corporate income tax, infrastructure and construction costs, free foreign exchange remittance, and so on. A partnership among national state governments is viewed as a positive condition for the successful operation of SEZs. This partnership process was also facilitated by the respective transnational provincial authorities, Zhejiang Province in China and Rayong in Thailand. Close alliances ("guanxi" in Chinese) of the public-private partnerships in Zhejiang Province have played a positive or catalytic role in the process of Chinese enterprises "going out," and attracting and assisting Chinese companies to invest and re-locate to the TCRIZ in Thailand. As a representative example of private enterprises "going out" in Zhejiang Province, the TCRIZ has successfully compiled all kinds of relevant data and information pertaining to Zhejiang. On the one hand, the Zhejiang provincial government and relevant institutions have actively set up public platforms, such as the Zhejiang Entrepreneur Alliance, for enterprises in Zhejiang to re-locate to Thailand. For instance, Zhejiang enterprises such as Zhongce Rubber and Dunan Rubber, are now well-established in the TCRIZ, and have become ambassadors for the Chinese-Thai industrial partnership. On the other hand, platforms at all levels have helped Chinese domestic enterprises, especially enterprises from Zhejiang, to open up new export market channels to Thailand, as a result of forming a cohesive industrial supply chain within the TCRIZ. In 2019, the TCRIZ was successfully enlisted as the flagship industrial park of the BRI in Zhejiang Province. In addition, the local governments in Rayong and Zhejiang Province maintain a positive partnership to promote bilateral trade and cultural exchanges.

\subsection{The China-Indonesia Economic and Trade Cooperation Zone}

The China-Indonesia Economic and Trade Cooperation Zone (Kawasan Industry Terpadu Indonesia China (KITIC)) was the first economic and trade cooperation zone to be set up by China in Indonesia, the main objectives being to integrate industrial production, logistics, warehousing, and trade. The KITIC is located in the Greenland International Industrial Center (GIIC) in the center of the Jakarta-Jakan Economic Belt, an industrial corridor in the east of Jakarta. The total area of the park at the planning stage was $4.9 \mathrm{~km}^{2}$; phase I had a construction area of $2.05 \mathrm{~km}^{2}$ and phase II had a planned area of $2.85 \mathrm{~km}^{2}$. The first phase adopted the hybrid partnership - 'garden within garden' - mode, which maintained a cooperative partnership with the GIIC; the second phase of the plan is to adopt an independent construction model, whereby an independent industrial park will be located next to phase I (Figure 2).

In November 2007, China's Ministry of Commerce gave official approval for the Guangxi State Farms Group (GSFG) to undertake the construction of the KITIC, becoming one of the first batch of 19 officially approved overseas economic and trade cooperation zones. Selection of the GSFG was due to two main considerations: on the one hand, there was a need for rapid development of an economic and trade partnership between Guangxi and Indonesia, 

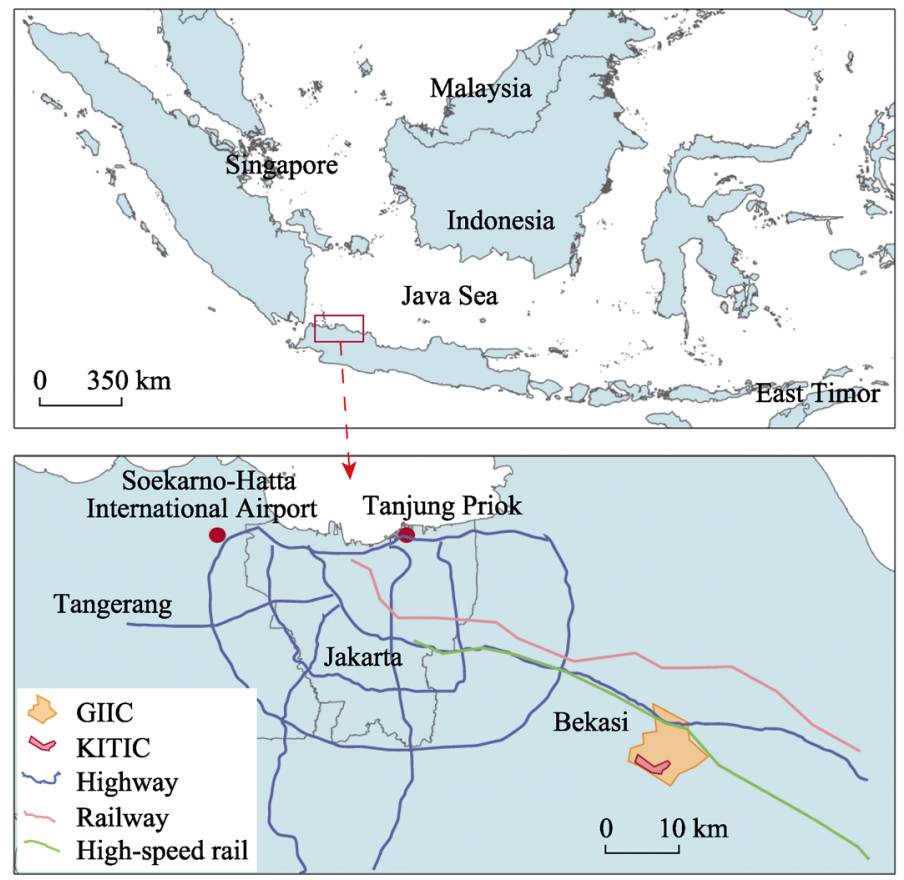

Figure 2 Location of the China-Indonesia Economic and Trade Cooperation Zone

hence Indonesia became Guangxi's second largest trading partner of ASEAN countries in 2006; on the other hand, the GSFG is a large state-owned enterprise operating directly under the Guangxi provincial government. The GSFG had extensive experience in the development and operation of industrial parks before undertaking the KITIC project, having direct involvement in foreign investment projects in Venezuela, Burma, Vietnam, and other countries, hence KITIC was suitably qualified to undertake the project in Indonesia.

The main functions and industrial positioning of KITIC include auto parts manufacturing, machinery manufacturing, processing of agricultural products, building materials, storage, and logistics services. In July 2011, the KITIC achieved a breakthrough in attracting investment. As of July 2020, the total investment for the KITIC and enterprises in the park was 1.2 billion US dollars. There are currently 55 enterprises in the KITIC, of which 28 are Chinese-funded, which account for approximately $50 \%$ of the enterprises. The remaining enterprises are mainly from Indonesia (31\%), Japan (9\%), France, New Zealand, Finland, Malaysia, and several other countries. The industrial sectors are mainly construction materials (20\%), auto parts (16\%), warehousing and logistics (15\%), food and beverage (9\%), etc. The KITIC includes many well-known enterprises, such as PT Construction (New Zealand), Fonterra Manufacturing Indonesia PT (New Zealand; the world's largest dairy exporter), and Mengniu Dairy Indonesia (China). As mentioned, the industrial investments are in the processing of agricultural products, food processing, machinery manufacture including heavy electrical engineering components such as transformers, automobile assembly, storage logistics, and so on.

The success of the KITIC in Indonesia is largely due to the hybrid cooperative partnership model established by the Sinar Mas Group (SMG). This partnership developed in three phases: 
Phase I - Exploratory cooperation from 2008 to 2012. GSFG sought partners in Indonesia and the SMG was identified. The SMG had investment projects in Guangxi Province, China. Through introductions by the Chinese Embassy in Indonesia and the Guangxi Bureau of Commerce, the cooperative partnership between GSFG and SMG was successfully established. The KITIC was formed in December 2008, the company being established as a joint venture between GSFG and the Indonesia Bumi Baraba Automobile Assembly Co., Ltd., the latter being mainly responsible for the development, construction, and operation of the zone. In August 2009, a land purchase agreement was formally signed with 205 hectares of land being obtained from the GIIC, which was subsequently controlled by SMG.

Phase II - A honeymoon period from 2012 to 2016: KITIC has responsibility for company expenditures and GIIC provides services. The construction of the KITIC infrastructure began in October 2009, and the breakthrough for investment was achieved in July 2011. The purchase of all land (205 hectares) occurred in 2013, and the infrastructure was then completed and transferred to GIIC, who then assumed the responsibility for maintenance and management of the infrastructure within the KITIC. At the same time, the KITIC pays a park management fee to GIIC on behalf of the enterprises in the park. In this way, the KITIC enterprises can not only enjoy the KITIC infrastructure and support services but also access a higher level of infrastructure support services provided by GIIC, such as water distribution facilities, sewage treatment plant, telecommunications center, and associated infrastructure, which includes an electricity substation $(150,000 \mathrm{KV})$, a residential area, a sports center, an amusement park, schools, clinics, supermarkets, banks, and other public service facilities.

Phase III - Partnership in Transition - beyond 2016: The KITIC seeks independence from the GIIC. Given that a shareholding partnership like the TCRIP has not been established, the KITIC is prone to experience from time to time financial crises. A number of ongoing issues including competition to attract investment will continue to occur, and KITIC has to meet the demands of GIIC with respect to rental and property fees. The KITIC's development strategy has been to seek independence by building on the phase II projects and freeing itself from the GIIC's restrictions. In August 2016, the KITIC passed the 'confirmation and assessment' of the Ministry of Commerce and the Ministry of Finance for Overseas Economic and Trade Cooperation zones. In September 2016, the KITIC and the Indonesian Chinese entrepreneur Lesdali General Manager Li Hongming signed the official cooperative development phase II agreement.

The role of the two partners, SMG and GSFG, is essentially that of a hybrid partnership. First, in the preparatory stages of investment, SMG helped GSFG acquire familiarity with Indonesian laws and relevant foreign investment policies and helped solve some of the problems encountered by enterprises when first entering Indonesia, such as land acquisition. Chinese enterprises face legal and institutional risks by investing in Indonesia. The GSFG initially chose an unscrupulous business partner for an early land acquisition deal before a final decision for land location had been taken and this poor decision resulted in financial loss. Second, in the development and construction stage, GIIC offers a complete infrastructure and support service package, which can provide enterprises in KITIC with the necessary investment, production, living, administration, and other support services, which clearly helps to reduce the development costs for KITIC. Third, in terms of attracting inward investment, there is a hidden cooperation process operating, because the two parks do not di- 
rectly offer help to each other to attract investment; it is more about attracting enterprises which can form sector-specific industrial clusters. For instance, GIIC is a park where Japanese enterprises have gathered, forming automobile, motorcycle, food processing, daily necessities, and other such industrial clusters. There are about 200 related enterprises stationed in GIIC, and these include world-renowned enterprises such as Suzuki, Bosch, and Honda. KITIC also has notable clusters of Chinese enterprises. Some enterprises in auto parts manufacturing, warehousing, and logistics services and other industries also serve GIIC enterprises, forming support facilities in the upstream and downstream segments of the supply chain.

KITIC and the enterprises in the park have paid more than 120 million USD in taxes and fees which, in part, supported the local economy. Overall, the enterprises employ more than 4000 people who are mostly Indonesians. Of the 51 employees in the KITIC, 38 are Indonesians, representing $75 \%$ of the workforce. The establishment of the KITIC has contributed very positively to the employment in the local region, has vigorously promoted the development of the local economy and society, and strengthened the corporate culture mindset of employees and facilitated integration in the local area; at the same time local customs and religious beliefs have been respected. For example, a prayer room was set up in the company's administrative building for Muslim staff to pray, and the working hours are shortened during Ramadan to minimize the workload of Muslim staff. The KITIC prides itself in public welfare, pays attention to peoples' livelihoods and seeks to give back to the local community with gratitude. Over many years, corporate support activities on an annual basis include funds for a local rural construction technology training center, financial help to socially vulnerable groups, organization of blood donations, and introduction of various practical measures to support the actions of the local government and village communities.

\subsection{Assembling these cases of transnational zone networks}

In this section we seek to stretch such concepts as transnational partnerships upon China's overseas SEZs studies beyond the above two cases. Having been enthusiastic proponents of the transnational partnerships, we would assemble each mode of transnational networks and their contribution to diffusing practices, tools and knowledge of China's overseas SEZs.

First, in both industrial parks cases (TCRIZ and KITIC), a good interactive relationship was formed between the TCRIZ and the Amata Urban Industrial Park, as well as between the KITIC and the GIIC. Although multinational or transnational corporations as the main agents expand production networks and/or penetrate markets across borders (Pereira, 2007), the strategic value of the joint venture established by sides, grounding SEZs and anchoring enterprises is evident. In almost all cases, states do play a part in assisting in the internationalization of transnational corporations; however, their role is often that of creating the 'architecture', or institutions, within which cross-border economic activities can take place (Pereira, 2007). Also should be noticed is that the government-linked corporation at all scales pave the way for the smooth operation of these SEZs. Significant progress has been made in each zone, and TCRIZ has come to fruition as initially expected and been salient among all China's overseas SEZs, seen in Table 3. The hybrid cooperative partnerships formed between the national state and local state governments together with leading enterprises from participating countries accelerates the realization of TPT. 
The second insight regarding to the case comparison is the powerful influence of coalitions of political and economic stakeholders over SEZs' development trajectories. It is enshrined that emphasis on hybrid partnership modes of the transnational networks through collaborations between government institutions at different scales and non-state actors across the traditional public-private divide, as well as the global North and South divide. As SDG17 ("Revitalize the global partnership for sustainable development") has called for, partnerships serve as a central strategy to implement sustainability action through collaboration across the traditional public-private divide (Westman et al., 2019).

A third observation relates to the typology of SEZs among BRI countries. Although we highlight the hybrid partnership mode by illustrating these two cases in Southeast Asia, we are not aiming to overshadow a vast of SEZs along the BRI featured spontaneous partnership and hierarchy partnership modes. It is also difficulty to count the typology of partnership modes of all SEZs among BRI countries. The grounds for comparing these three modes from quite different contexts rest on the shared features of Chinese SEZs along the BRI countries. That is, the main driver of transnational partnerships is the multinational corporation, state-owned enterprises (SOE) in the hierarchical partnership mode or private enterprises in the spontaneous partnership mode, which 'goes abroad' in order to search for more 'efficient' factors of production, and (or) to embed into the local or springboard markets. However, it is needed in practice that coordinating a multiplicity of institutional actors and sustaining development in the face of changing institutional, political, policy and economic challenges (Robinson et al., 2020). As for the hybrid partnership mode, combining both the advantages of state-geared policies and private entrepreneurship, it has proved salient and should be embraced as crucial for territorially embedding investments in host countries.

Table 3 Economic profiles of two case studies

\begin{tabular}{lll}
\hline \multicolumn{1}{c}{ Case studies } & \multicolumn{1}{c}{ TCRIZ } & \multicolumn{1}{c}{ KITIC } \\
\hline \multicolumn{1}{c}{ Land covering } & \multicolumn{1}{c}{$12 \mathrm{~km}^{2}$} & \multicolumn{1}{c}{$4.9 \mathrm{~km}^{2}$} \\
$\begin{array}{l}\text { Economic and employ- } \\
\text { ment performances }\end{array}$ & $\begin{array}{l}\text { Investment amounts: more than 3.9 billion } \\
\text { USD; employment: 34 thousand in 2020 }\end{array}$ & $\begin{array}{l}\text { Investment amounts: more than 1.2 billion } \\
\text { USD; employment: 4 thousand in 2020 }\end{array}$ \\
$\begin{array}{l}\text { Approved enterprises with } \\
\text { foreign investment in this } \\
\text { zone (by 2020) }\end{array}$ & More than 150 Chinese enterprises & $\begin{array}{l}\text { 55 enterprises, of which 50\% Chinese } \\
\text { enterprises }\end{array}$ \\
& $\begin{array}{l}\text { Building materials, motorcycle assembly, } \\
\text { auto parts manufacturing, automobile } \\
\text { assembly, warehousing and logistics, etc. }\end{array}$ & $\begin{array}{l}\text { Agricultural products processing, food } \\
\text { processing, machinery manufacturing, } \\
\text { transformer, automobile assembly, } \\
\text { warehousing and logistics, etc. }\end{array}$ \\
\hline
\end{tabular}

\section{Conclusions and discussion}

Chinese overseas industrial parks are important platforms and facilitators of the BRI. China has many overseas industrial parks, all of which embrace diverse institutional environments. These partnerships play a key role in facilitating the mobilization of the transnational policies of the parks. From the perspective of the ANT, this paper has addressed the role of multi-participant partnerships in the policy mobility of different types of overseas parks. China has more than 100 overseas SEZs along the BRI and these can be divided into three types according to the different partnership modes for transnational policy mobilization, namely, hierarchical partnership, spontaneous partnership, and hybrid partnership. The hier- 
archical partnership is state-led with a top-down structure, and such partnerships reflect a comparability of the local and host country policies and a combination of preferential policies and guarantees. The spontaneous partnership is a kind of bottom-up relationship and the main objective is to maximize profits. The hybrid partnership is a combination of the top-down and bottom-up approaches in which multiple actors, including the state, the local government, the local people, and enterprises all have important roles to play.

An empirical study of the hybrid partnership concept was examined by undertaking a scenario analysis of two Chinese overseas SEZs, that is, the TCRIZ in Thailand and the KITIC in Indonesia, respectively. These case studies illustrated the growing importance of multi-scalar partnerships in the landscape of Chinese SEZs and TPT in various contexts throughout countries in the BRI. Notably, the hybrid partnership mode of the multi- transnational actor network, coupled with the political and economic significance of flagship projects in the BRI, makes these two industrial parks unique cases of TPT that deserves close study. For comparison purposes, both of these two industrial parks (TCRIZ and KITIC), characterized by the 'garden-within-garden' partnership mode, evidently have clear merits. A good interactive relationship was formed between the TCRIZ and the Amata Urban Industrial Park, as well as between the KITIC and the GIIC. The hybrid cooperative partnerships formed between the national state and local state governments together with leading enterprises from participating countries accelerates the realization of TPT. The leading enterprises in the host countries, the Amata Company in Thailand and the GIIC in Indonesia, enjoy economic and social benefits together with the professional management expertise of TCRIZ and KITIC, respectively. Although these partnerships in the early days were mainly concerned with profit generation and attracting DFI, both industrial parks gained added momentum by scaling up policy transfer through cooperative engagements with bilateral actors at the community, urban, regional, and national state levels. Finally, it should be noted that the Indonesia case study, which illustrates the 'park-within-park' mode was far from 'the key that opens all doors.' By contrast, for the hybrid mode, the two leading enterprises have to ensure a balanced approach in terms of their functions, resources, motivations, and benefits, otherwise there would be competition between each organization to attract inward investment.

Against the background of the BRI, the construction of overseas industrial parks has become an irresistible trend. Therefore, the following suggestions are considered beneficial to the construction of overseas parks: Shocked by recent COVID-19 pandemic, the oversea industrial parks need to increase its inner resilience capacity due to the high degree of volatility and uncertainty in global economic waves. The construction of overseas industrial parks should be strategically planned and monitored by the national state to avoid haphazard and disorderly construction. This reinforces the need for policy mobilities scholarship to pay attention to the structural contexts - specifically, state-level geopolitical relationships - of transnational policy mobilization (Bok, 2020). Both national state governments need to establish bilateral dialogue and communication mechanisms, strengthen financial and investment guarantees for prospective enterprises, as well as effectively regulate the competition by external enterprises. Additionally, this paper also highlights the hybrid partnership mode, which requires long-term partnership at all scales in order to critically assess the claims of all stakeholders who will work together to promote the development of overseas industrial 
parks. Taking full advantage of the host country and considering the local development conditions, there is a need for the various actors to play full roles in the multi-level cooperative partnership to achieve full integration and ensure the TPT of overseas industrial zones.

\section{References}

Adams D, Hastings EM, 2001. Urban renewal in Hong Kong: Transition from development corporation to renewal authority. Land Use Policy, 18(3): 245-258.

Adams D, Hastings E M, 2001. Assessing institutional relations in development partnerships: The Land Development Corporation and the Hong Kong Government prior to 1997. Urban Studies, 38(9): 1473-1492.

Aka KG, 2019. Actor-network theory to understand, track and succeed in a sustainable innovation development process. Journal of Cleaner Production, 225: 524-540.

Alkon M, 2018. Do special economic zones induce developmental spillovers? Evidence from India's States. World Development, (107): 396-409.

Bok R, 2020. The relational co-production of "success" and "failure," or the politics of anxiety of exporting urban “models" elsewhere. Urban Geography, 41(9): 1218-1239, doi: 10.1080/02723638.2020.1802932.

Caroline Y, Victor S, Wilfred H, 2007. Transborder industrialization in the framework of Singapore's regionalization strategy: The case of Singapore's Gambit in Vietnam. Journal of Asia-Pacific Business, 8(3): 63-90.

Cheng H, Liu Y, He S et al., 2017. From development zones to edge urban areas in China: A case study of Nansha, Guangzhou City. Cities, 71(11): 110-122.

Chou T L, Lin Y C, 2007. Industrial park development across the Taiwan Strait. Urban Studies, 44(8): $1405-1426$.

Dabrowski M, 2014. EU cohesion policy, horizontal partnership, and the patterns of sub-national governance: Insights from Central and Eastern Europe. European Urban and Regional Studies, 21(4): 364-383.

Derkzen P, 2010. Rural partnerships in Europe, a differentiated view from a country perspective: The Netherlands and Wales. European Urban \& Regional Studies, 17(1): 17-30.

Doucette J, Lee S O, 2015. Experimental territoriality: Assembling the Kaesong Industrial Complex in North Korea. Political Geography, 47: 53-63.

Farole T, Akinci G, 2011. Special economic zones: Progress, emerging challenges, and future directions. The World Bank.

Giannecchini P, Taylor I, 2018. The eastern industrial zone in Ethiopia: Catalyst for development? Geoforum, 88: $28-35$.

Holden, Chris, 2017. Graduated sovereignty and global governance gaps: Special economic zones and the illicit trade in tobacco products. Political Geography, 59: 72-81.

Huang Z, He C, Wei Y H D, 2016. A comparative study of land efficiency of electronics firms located within and outside development zones in Shanghai. Habitat International, 56: 63-73.

Kitajima S, 1998. Industrial and regional restructuring and changing form of state intervention: The development of partnerships in postwar Japan. International Journal of Urban \& Regional Research, 22(1): 26-41.

Liang Zhuang, Chao Ye, Senlin $\mathrm{Hu}, 2019$. Spatial production and spatial dialectic: Evidence from the new urban districts in China. Journal of Geographical Sciences, 29(12): 1981-1998.

Liu Weidong, Dunford M, 2016. Inclusive globalization: Unpacking China's Belt and Road Initiative. Area Development and Policy, 1(3): 323-340.

Liu Yungang, Ye Qinglu, 2015. Territorialization and territorial politics in the urban grassroots of China. Acta Geographica Sinica, 70(2): 283-296. (in Chinese)

Liu Zhigao, Wang Tao, 2020. The multi-scale coupling construction mechanism of China's overseas intergovernmental cooperation parks: A case study of China-Belarus Industrial Park. Acta Geographica Sinica, 75(6): 1185-1198. (in Chinese)

Luo X, Shen J, 2009.A study on inter-city cooperation in the Yangtze River Delta region, China. Habitat International, 33(1): 52-62. 
Marsh D, Sharman J C, 2009. Policy diffusion and policy transfer. Policy Studies, 30(3): 269-288.

Mccann E J, 2011. Urban policy mobilities and global circuits of knowledge: Toward a research agenda. Urban Insight, 101(1): 107-130.

McCann E, Ward K, 2012. Policy assemblages, mobilities and mutations: Toward a multidisciplinary conversation. Political Studies Review, 10(3): 325-332.

Meng Guangwen, Wang Hongling, Yang Shuang, 2015. Study on evolution and dynamic mechanism of Tianjin Pilot Free Trade Zone. Acta Geographica Sinica, 70(10): 1552-1565. (in Chinese)

Miao J T, 2018. Parallelism and evolution in transnational policy transfer networks: The case of Sino-Singapore Suzhou Industrial Park (SIP). Regional Studies, 52(9): 1191-1200.

Moberg L, 2017. The Political Economy of Special Economic Zones: Concentrating Economic Development. Routledge.

Ong A, 2004. The Chinese axis: Zoning technologies and variegated sovereignty. Journal of East Asian Studies, 4(1): 69-96.

Ortegel M, 2017. Creative city policy mobilities as transformations of dispositives-arrangements of 'networking' in the European Metropolitan Region of Nuremberg. Geographica Helvetica, 72(2): 157-169.

Ortmann S, Thompson M R, 2014. China's obsession with Singapore: Learning authoritarian modernity. The Pacific Review, 27(3): 433-455.

Pereira A A, 2004. State entrepreneurship and regional development: Singapore's industrial parks in Batam and Suzhou. Entrepreneurship \& Regional Development, 16(2): 129-144.

Pereira A A, 2007. Transnational state entrepreneurship? Assessing Singapore's Suzhou Industrial Park project (1994-2004). Asia Pacific Viewpoint, 48(3): 287-298.

Phelps N A, 2007. Gaining from Globalization? State extraterritoriality and domestic economic impacts: The case of Singapore. Economic Geography, 83(4): 371-393.

Rithmire M, 2013. Land politics and local state capacities: The political economy of urban change in China. The China Quarterly, (216): 872-895.

Robinson J et al., 2020. Financing urban development, three business models: Johannesburg, Shanghai and London. Progress in Planning, https://doi.org/10.1016/j.progress.2020.100513.

Shaw M P, Yeoh C, 2000. Singapore's overseas industrial parks. Regional Studies, 34(2): 199-206.

Song Tao, Liu Weidong, Liu Zhigao et al., 2018. Chinese overseas industrial parks in Southeast Asia: An examination of policy mobility from the perspective of embeddedness. Journal of Geographical Sciences, 28(9): 1288-1306.

Song Tao, Liu Weidong, Gao Boyang et al., 2020. Policy mobility of China's overseas industrial zones in the lens of partnership: A case study of Thai-Chinese Rayong Industrial Zone. Acta Geographica Sinica, 75(6): 1199-1209. (in Chinese)

Stephen S, 2016. The Politics of Partnership. European Urban and Regional Studies. Strategic on AEC.

Taira A, 2020. Beyond the cluster: A case study of pipelines and buzz in the local relational space of the glove-related industry of Shikoku, Japan. The Geographical Journal, 186(1): 45-58.

Temenos C, McCann E, 2012.The local politics of policy mobility: Learning, persuasion, and the production of a municipal sustainability fix. Environment and Planning A, 44(6): 1389-1406.

Ward K, 2018. Policy mobilities, politics and place: The making of financial urban futures. European Urban and Regional Studies, 25(3): 266-283.

Westman L K, Castán Broto, Vanesa Huang P, 2019. Revisiting multi-level governance theory: Politics and innovation in the urban climate transition in Rizhao, China. Political Geography, 70: 14-23.

Ye Chao, LI Simeng, Zhuang Liang et al., 2020. A comparison and case analysis between domestic and overseas industrial parks of China since the Belt and Road Initiative. Journal of Geographical Sciences, 30(8): 1266-1282.

Yeung W C, 2005. The firm as social networks: An organisational perspective. Growth and Change, 36(3): $307-328$. 